để đánh giá tình trạng thoái khớp gối. Nó là một hình chiếu hai chiều của các cấu trúc khớp ba chiều. Điều này tạo ra một điều kiện tiên quyết cho các biến thể của hình ảnh ở các vị trí khác nhau của không gian khớp. Chụp X-quang ở tư thế gập gối cố định cung cấp thông tin đáng tin cậy về khe khớp ở bệnh nhân thoái hóa khớp gối mức độ trung bình. Để khách quan hóa kêt quả chụp $X$ quang thông thường trong thực hành và nghiên cứu lâm sàng, các phương pháp định lượng và bán định lượng được sử dụng để đánh giá thoái hóa khớp gối. Thang điểm của Kellgren và Lawrence được sử dụng rộng rãi trong hệ thống 5 điểm để đánh gía thoái hoá khớp gối. Tuy nhiên, cần lưu ý rằng những triệu chứng của bện không phải lúc nào cũng tương ứng với những thay đổi cấu trúc được đánh giá bởi hình ảnh Xquang. Do đó, trong quá trình chẩn đoán và điều trị cần có phương pháp tiếp cận phối hợp để đánh giá chính xác mức độ nghiêm trọng của bệnh.

\section{TÀI LIÊU THAM KHẢO}

1 Kellgren JK, Lawrence JS. Radiological assessment of osteoarthritis. Ann Rheum Dis 1957; 16:494-501

2 Culvenor, Adam G., et al. "Defining the presence of radiographic knee osteoarthritis: a comparison between the Kellgren and Lawrence system and OARSI atlas criteria." Knee Surgery, Sports Traumatology, Arthroscopy 23.12 (2015): 3532-3539.

3 Arden, Nigel, and Michael C. Nevitt. "Osteoarthritis: epidemiology." Best Practice \& Research Clinical Rheumatology 20, no. 1 (2006): 3-25.

4 Loeser, Richard F., et al. "Osteoarthritis: a disease of the joint as an organ." Arthritis \& Rheumatism 64.6 (2012): 1697-1707.

5 Messieh SS, Fowler PJ, Munro T. Anteroposterior radiographs of the osteoarthritic knee. J Bone Joint Surg Br 1990;72(4):639-640

6 LaValley, Michael P., et al. "The lateral view radiograph for assessment of the tibiofemoral joint space in knee osteoarthritis: its reliability, sensitivity to change, and longitudinal validity." Arthritis \& Rheumatism 52.11 (2005): 3542-3547

\title{
ĐÁNH GIÁ SỰ HÀI LÒNG CỦA NGƯờI BÊNH ĐỐI VỚI DİCH VỤ CHẨN ĐOÁN HİNH ẢNH TẠI BỆNH VIỆN ĐA KHOA TRUNG TÂM TIỀN GIANG NĂM 2021
}

\section{TÓM TẮT}

Đặt vấn đề: chẩn đoán hình ảnh ( $\mathrm{CĐHA)} \mathrm{là} \mathrm{một}$ thành phần của dịch vu y tế, với tư cách là nhà cung cấp dịch vụ, các cơ sở cung cấp dịch vụ CĐHA cần hiểu chất lượng dịch vụ mà mình cung cẩp, về sự hài lòng của khách hàng và các vấn đề liên quan. Mục tiêu: Mô tả sư hài lòng của người bênh và bác sĩ lậm sàng đối với dịch vụ chẩn đoán hình ảnh của Bệnh viện Đa khoa Trung tâm Tiền Giang, năm 2021. Thiết kể nghiên cứu: mô tả cắt ngang. Kết quả: Nghiên cứu trên 280 người bệnh (NB) ghi nhân: Tỉ lệ hài lòng chung của người bệnh về dịch vụ chẩn đoán hình ảnh là $67,14 \%$. Hài lòng đối với từng yếu tố: yếu tố tin cậy đạt 75,36\%; yếu tố đáp ứng đạt Tỉ lệ 72,86\%; về nẳng lực phục vụ đạt 76,79\%; yểu tố hữu hinh đạt Tỉ lệ $74,64 \%$; yếu tố đồng cảm đạt 73,93\%. Kết luận: mức độ hài lòng của người bệnh khá cao, tuy nhiên cần thực hiện một số giải pháp nâng cao chất lượng dich vu CĐHA

Tư khóa: sự hài lòng, người bệnh (NB), chẩn đoán hình ảnh (CॄĐHA)

${ }^{1}$ Bệnh viện Đa khoa Trung tâm Tiền Giang Chịu trách nhiệm chính: Nguyễn Thị Bạch Tuyết Email: bachtuyettiengiang@gmail.com Ngày nhận bài: 16.8 .2021

Ngày phản biện khoa học: 11.10.2021

Ngày duyệt bài: 18.10.2021

\section{SUMMARY}

\section{THE SATISFACTION OF PATIENTS WITH THE DIAGNOSTIC IMAGING SERVICES OF TIEN GIANG CENTRAL GENERAL HOSPITAL IN 2021}

Background: Diagnostic imaging is a component of medical services, as service providers, the service providers need to understand the quality of the services they provide on customer satisfaction and related issues. Objective: Describe the satisfaction of patients and clinicians with the diagnostic imaging services of Tien Giang Central General Hospital in 2021. Methods: Cross-sectional description. Results: A study on 280 patients recorded: The overall satisfaction rate of patients with imaging services was $67.14 \%$. Satisfied with each factor: reliability factor reached $75.36 \%$; response factor reached the rate of $72.86 \%$; service capacity reached $76.79 \%$; tangible elements reached the rate of $74.64 \%$; empathy factor reached $73.93 \%$. Conclusion: Patient's satisfaction is quite high, however, it is necessary to implement some solutions to improve the quality of diagnostic imaging services.

Keywords: satisfaction, patients, diagnostic imaging.

\section{I. ĐẶT VẤN ĐỀ}

Sự hài lòng của khách hàng đối với cơ sở y tế hiện nay đã trở thành tiêu chí quan trọng trong việc đánh giá chất lượng bệnh viện theo tiêu chí 
của Bộ $Y$ tế ban hành ${ }^{(1)}$. Đánh giá sự hài lòng của khách hàng nhằm mục đích nâng cao chất lượng dịch vụ y tế cũng như sự nhận thức của người dân về quyền được hưởng những dịch vụ chăm sóc sức khỏe tốt nhất, sự hài lòng của người bệnh dẫn đến quyết định lựa chọn cơ sở khám chữa bệnh, tạo nên những khách hàng trung thành. Chẩn đoán hình ảnh ( $\mathrm{CDHA})$ hay hình ảnh học lâm sàng là ngành ứng dụng các kỹ thuật khoa học công nghệ vào chẩn đoán y học CĐHA là một thành phần của dịch vụ y tế, với tư cách là nhà cung cấp dịch vụ, các cơ sở cung cấp dịch vụ CĐHA cần hiểu chất lượng dịch vụ mà mình cung cấp, về sự hài lòng của khách hàng và các vấn đề liên quan ${ }^{(3)}$.

Bệnh viện Đa khoa Trung tâm Tiền Giang là bệnh viện hạng 1 tuyến tỉnh, hàng năm Phòng Quản lý chất lượng có khảo sát sự hài lòng người bệnh dựa theo 83 tiêu chí đánh giá chất lượng bệnh viện của BYT ban hành. Theo báo cáo tổng kết quý 3 năm 2020 cho biết sự hài lòng chung của người bệnh đối với các dịch vụ y tế cuả bệnh viện là $90 \%$, trong khi $80 \%$ hài lòng với dịch vụ khám chữa bệnh của khối ngoại trú và cận lâm sàng, trong đó có $\mathrm{C} Đ H A^{(3)}$. Thực tế cho đển hiên nay, chưa có kết quả khảo sát nào tại bệnh viện được công bố đề cập đến sự hài lòng của bác sĩ lâm sàng và người bệnh về dịch vụ CĐHA. Vì thế, chúng tôi thực hiện đề tài này nhằm tìm hiểu một cách bao quát hơn về sự hài lòng của người bệnh cũng như các vấn đề liên quan đến dịch vụ CĐHA tại bệnh viện. Mục tiêu nghiên cứu:

Mô tả sự hài lòng của người bênh đối với dịch vụ chẩn đoán hinh ảnh tại Bênh viện Đa khoa Trung tâm Tiền Giang, năm 2021

\section{II. ĐỐI TƯỢNG VÀ PHƯƠNG PHÁP NGHIÊN CỨU}

Đối tượng nghiên cứu: Người bệnh đến sử dụng dịch vụ CĐHA tại khoa CĐHA Bệnh viện Đa khoa Trung tâm Tiền Giang

- Tiêu chí lưa chon: người bệnh trên 18 tuổi, có khả năng trả lời các câu hỏi điều tra và đồng ý tham gia nghiên cứu.

- Tiêu chí loại trừ: Những người từ chối tham gia nghiên cứu

Thời gian nghiên cứu: Từ 10/2020 đến 10/2021 mô tả

Thiết kế nghiên cứu: nghiên cứu cắt ngang

Cỡ mẫu và phương pháp chọn mẫu

- Sử dụng công thức cõ̃ mẫu so sánh một tỉ lệ:

$$
n=Z^{2}(1-a / 2) \frac{p(1-p)}{d^{2}}
$$

+ Z: Độ tin cậy; khi $a=0,05$, độ tin cậy 95\%: $Z=1,96$

$+p=0,8$ (Tỉ lệ người bệnh hài lòng với dịch vụ Khám chữa bệnh của khối ngoại trú và cận lâm sàng theo báo cáo của Phòng Quản lý chất lượng BV là $80 \%$ )

$+d=0,05$ (Độ sai số $5 \%$ ).

$\Rightarrow \mathrm{n}=246$, dự phòng $10 \%$ đối tượng từ chối tham gia nghiên cứu, vậy cỡ mẫu là 280 người.

- Chọn mẫu: sử dụng phương pháp chọn mẫu ngẫu nhiên. Trung bình mỗi ngày khoa CẺHA có ít nhất khoảng 300 người bệnh đến sử dụng dịch vụ CĐHA, phân bố theo tỉ lệ Siêu âm: X quang: $C T$ và $M R I$ là 2:2:1. Mỗi ngày chọn 15 mẫu theo tỉ lệ trên cho đến đủ số lượng người bệnh là 280 người (siêu âm 112 người; chụp X quang 112 người; chụp CT hoặc MRI 56 người)

Công cụ thu thập số liệu: Bộ câu hỏi phỏng vấn đánh giá sự hài lòng kỳ vọng và đánh giá sự hài lòng thực tể, được soạn dựa trên công cụ đo lường sự hài lòng của khách hàng (SERVQUAL) của Parasuraman và thang đo Likert chia thành 05 mức độ để đánh giá (7).

Phân tích số liệu: bằng phần mềm SPSS 18.0

\section{KẾT QUẢ NGHIÊN CỨU} cứu

\section{Thông tin chung của đối tượng nghiên}

Bảng 1 Thông tin về đặc điểm chung của người bênh

\begin{tabular}{|c|c|c|}
\hline Đặc điểm (n=280) & Tân số & Tỉ lệ (\%) \\
\hline - Tuối & & \\
\hline Từ 18 - dưới 25 tuổi & 57 & 20,36 \\
\hline Từ 25 - 40 tuổi & 90 & 32,14 \\
\hline Trên 40 tuối & 133 & 47,50 \\
\hline - Giới & & \\
\hline Nam & 138 & 49,29 \\
\hline Nữ & 142 & 50,71 \\
\hline - Nghề nghiệp & & \\
\hline Nông dân & 57 & 20,36 \\
\hline Lao động tự do & 180 & 64,29 \\
\hline Cán bộ, viên chức & 43 & 15,36 \\
\hline - Nơi ở & & \\
\hline Thành thị & 105 & 37,50 \\
\hline Nông thôn & 175 & 62,50 \\
\hline - Trình độ học vấn & & \\
\hline Đại học & 46 & 16,43 \\
\hline $\begin{array}{c}\text { Tốt nghiệp phổ thông } \\
\text { trung học }\end{array}$ & 78 & 27,86 \\
\hline Khác & 156 & 55,71 \\
\hline
\end{tabular}
CĐHA 
Bảng 2. Sự hài lòng theo thành phàn "Tin cậy"

\begin{tabular}{|c|c|c|c|}
\hline $\begin{array}{l}\text { Nô̂i dung } \\
(n=280)\end{array}$ & $\begin{array}{c}\text { Tỉ lệ } \\
\text { hài lòng }(\%)\end{array}$ & $\begin{array}{l}\text { Điểm } \\
\text { trung bình }\end{array}$ & $\begin{array}{l}\text { Độ lệ̂ch } \\
\text { chuẩn }\end{array}$ \\
\hline Các báo cáo kết quả chấn đoán CĐHA rõ ràng & 81,43 & 4,09 & 0,829 \\
\hline Công khai quy trình CĐHA & 83,57 & 4,14 & 0,868 \\
\hline $\begin{array}{c}\text { NB nhần được thông tin đầy đủ về tình trạng bệnh } \\
\text { và được hướng dẫn trở lại khoa lâm sàng }\end{array}$ & 82,50 & 4,11 & 0,807 \\
\hline NB cảm thấy tin tưởng và̀o kết quả CĐHA & 82,14 & 4,15 & 0,822 \\
\hline Hài lòng chung về yếu tố tin cậy & 75,36 & 4,12 & 0,74 \\
\hline
\end{tabular}

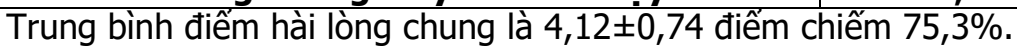

Bảng 3. Sự hài lòng theo thành phần "Đáp ứng"

\begin{tabular}{|c|c|c|c|}
\hline $\begin{array}{c}\text { Nội dung } \\
(\mathbf{n = 2 8 0 )}\end{array}$ & $\begin{array}{c}\text { Tỉ lệ hài } \\
\text { lòng (\%) }\end{array}$ & $\begin{array}{c}\text { Điểm } \\
\text { trung bình }\end{array}$ & $\begin{array}{c}\text { Độ lệ̂̉ } \\
\text { chuẩn }\end{array}$ \\
\hline NB được khám theo đúng thứ tự & 81,43 & 4,15 & 0,833 \\
\hline NB được thông báo chính xác về thời gian khám & 78,93 & 4,12 & 0,836 \\
\hline và trả kết quả CĐHA & 77,86 & 4,10 & 0,847 \\
\hline Tố chức thực hiện dịch vụ linh hoạt & 77,86 & 4,11 & 0,887 \\
\hline Dịch vụ CĐHA đáp ứng kịp thời & $\mathbf{7 2 , 8 6}$ & $\mathbf{4 , 1 2}$ & $\mathbf{0 , 7 8}$ \\
\hline Hài lòng chung về yếu tố đáp ứng &
\end{tabular}

Sự hài lòng về yếu tố người bệnh được khám đúng theo số thứ tự chiếm cao nhất $(81,4 \%)$, các yếu tố khác đạt từ $77 \%$ đến $78 \%$.

Bảng 4. Sự hài lòng theo thành phần "Năng lực phục vụ"

\begin{tabular}{|c|c|c|c|}
\hline $\begin{array}{c}\text { Nội dung } \\
(\mathbf{n = 2 8 0 )}\end{array}$ & $\begin{array}{c}\text { Tì̉ lệ hài } \\
\text { lòng (\%) }\end{array}$ & $\begin{array}{c}\text { Điếm } \\
\text { trung bình }\end{array}$ & $\begin{array}{c}\text { Độ lệ̂́ch } \\
\text { chuấn }\end{array}$ \\
\hline NVYT luôn tỏ ra lịch sự, tôn trọng vấn đề riêng tư của NB & 84,64 & 4,24 & 0,784 \\
\hline NVYT thực hiện cuộc khám một cách tỉ mỉ, toàn diện & 80,71 & 4,15 & 0,829 \\
\hline NB tin tưởng vào NVYT khoa CDHA & 80,71 & 4,14 & 0,846 \\
\hline NVYT có kiến thức tốt đế trả lời những câu hỏi của NB & 81,07 & 4,17 & 0,845 \\
\hline Hài lòng chung về năng lực phục vụ & $\mathbf{7 6 , 7 9}$ & $\mathbf{4 , 1 7}$ & $\mathbf{0 , 7 5}$ \\
\hline
\end{tabular}

Sự hài lòng chung về năng lực phục vụ chiếm $76,79 \%$ với sự hài lòng về yếu tố NVYT luôn tỏ ra lịch sự, tôn trọng vấn đề riêng tư của NB chiếm cao nhất $(84,6 \%)$

Bảng 5. Sự hài lòng theo thành phần "Hữu hinh"

\begin{tabular}{|c|c|c|c|}
\hline $\begin{array}{c}\text { Nội dung } \\
\text { (n=280) }\end{array}$ & $\begin{array}{c}\text { Tỉ lệ hài } \\
\text { lòng (\%) }\end{array}$ & $\begin{array}{c}\text { Điếm trung } \\
\text { bình }\end{array}$ & $\begin{array}{c}\text { Đố lệch } \\
\text { chuẩn }\end{array}$ \\
\hline $\begin{array}{c}\text { Nơi ngồi chờ sạch sẽ, về sinh, các phòng chụp phim } \\
\text { và siêu ẩm ngăn năp }\end{array}$ & 77,86 & 4,14 & 0,830 \\
\hline NVYT ăn măăc sạch sẽ, gọn gàng & 86,07 & 4,24 & 0,779 \\
\hline Trang thiết bị,, phương tiện chấn đoán đây đủ & 84,29 & 4,20 & 0,795 \\
\hline NVYT vui vè, hoà nhã khi tiếp xúc với NB & 84,64 & 4,22 & 0,798 \\
\hline Hài lòng chung về yếu tố hữu hình & $\mathbf{7 4 , 6 4}$ & $\mathbf{4 , 2 0}$ & $\mathbf{0 , 7 5}$ \\
\hline
\end{tabular}

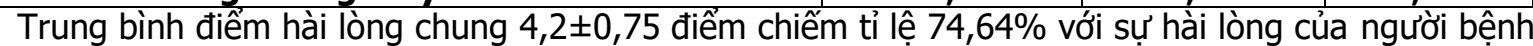
về các NVYT ăn mặc sạch sẽ, gọn gàng $86,07 \%$ (cao nhất)

Bảng 6. Sự hài lóng theo thành phần "Đồng cảm"

\begin{tabular}{|c|c|c|c|}
\hline $\begin{array}{l}\text { Nô̂i dung } \\
(\mathbf{n}=\mathbf{2 8 0})\end{array}$ & $\begin{array}{l}\text { Tỉ lệ hài } \\
\text { lòng (\%) }\end{array}$ & $\begin{array}{l}\text { Điểm } \\
\text { trung bình }\end{array}$ & $\begin{array}{l}\text { Độ lệch } \\
\text { chuẩn }\end{array}$ \\
\hline $\begin{array}{l}\text { NVYT khoa CĐHA giải thích rõ ràng và yêu câu hợp tác } \\
\text { khi thực hiện kỹ thuật CĐHA }\end{array}$ & 79,64 & 4,15 & 0,835 \\
\hline $\begin{array}{c}\text { NVYT khoa CĐHA chia sẻ, động viên trước những lo } \\
\text { lắng về bệnh tật. }\end{array}$ & 77,50 & 4,09 & 0,879 \\
\hline NVYT luôn sằn lòng giúp đỡ người bệnh & 80,36 & 4,15 & 0,848 \\
\hline $\begin{array}{l}\text { Thời gian thực hiện kỹ thuật CĐHA phù hợp, đáp ứng } \\
\text { kịp thời cho NB }\end{array}$ & 81,79 & 4,19 & 0,814 \\
\hline Hài lòng chung về yếu tố đồng cảm & 73,93 & 4,15 & 0,79 \\
\hline
\end{tabular}

Trung bình điểm hài lòng chung $4,15 \pm 0,79$ điếm chiếm tỉ lệ $73,93 \%$. 
Bảng 7. Sứhài lòng chung của người bênh. Nội dung $\quad$ Chưa hài $\quad$ Hài lòng $(\mathbf{n}=\mathbf{2 8 0}) \quad$ lòng $\mathbf{n}(\%) \quad n(\%)$

\begin{tabular}{|l|l|l}
\hline Sự hài lòng chung & $92(32,86)$ & $188(67,14)$ \\
\hline
\end{tabular}

Kết quả khảo sát trên 280 người bệnh cho thấy tỉ lệ hài lòng trung bình của 5 khía cạnh "Tin cậy"; "Đáp ứng"; Phục vụ"; "Hữu hình"; "Đồng cảm" đều đạt khoảng $75 \%$ và tỉ lệ không hài lòng đạt khoảng $25 \%$.

\section{BÀN LUÂN}

1. Đặc điểm chung về đối tượng nghiên cứu. Trong số 280 đối tượng tham gia nghiên cứu, chúng tôi thấy đối tượng người bệnh đến sử dụng dịch vụ CĐHA phân bố về giới tính không có sự khác biệt với tî lệ lần lượt $50,71 \%$ là nữ và 49,29\% là nam, độ tuổi trên và dưới 40 tuổi có tỉ lệ gần bằng nhau lần lượt là $47,5 \%$ và $52,5 \%$, có thể nói đặc điểm tuổi và giới tính của người bệnh không ảnh hưởng đến sự hài lòng về dịch vụ CĐHA trong nghiên cứu này. Khác với tác giả Wafaa bằng nghiên cứu cắt ngang trên 306 người bệnh tại bệnh viện đại học Fayoum thì cho thấy cảm nhận về sự hài lòng người bệnh với dịch vụ $X$ quang có liền quan ý nghĩa đối với độ tuổi của các trường hợp trẻ hơn, nhóm người trẻ sẽ có tỉ lệ hài lòng cao hơn $(p<0.05)^{(8)}$, còn trong kết quả nghiên cứu của tác giả Nguyễn Quốc Việt tại khoa khám của bệnh viện Chỉnh hình và Phục hồi chức năng TP HCM, người có tuổi trên 40 thì hài lòng cao gấp 2,04 lần so với những người có độ tuổi dưới 40 , nữ có tỉ lệ hài lòng cao gấp 1,83 lần so với nam (6).

Về trình độ học vấn, số người bệnh tham gia nghiên cứu từ tốt nghiệp THPT trở lển chiếm tỉ lệ $44,29 \%$, số người bệnh có trình độ học vấn dưới THPT có tỉ lê $55,71 \%$, có thể có sự khác nhau về trình độ học vấn dẫn đến sự hài lòng về dịch vụ khác nhau, người có trình độ học vấn cao thường có xu hướng chi tiết hơn khi cảm nhận về chất lượng dịch vụ và khó hài lòng hơn, họ thường mong muốn lựa chọn các bệnh viện tuyến trên để khám bệnh, người có trình độ học vấn thấp hơn thì dễ hài lòng hơn. Đặc điểm này tương tự như trong nghiên cứu của Wafaa cũng cho thấy người có trình độ học vấn thấp thì sẽ có tỉ lệ hài lòng cao hơn ${ }^{(8)}$. Nghiên cứu của tác giả Vương Quan Thành về dịch vụ khám bệnh ngoại trú tại khoa khám BV Quân Dân Y tỉnh Đồng tháp cũng cho thấy khi đối tượng tham gia nghiên cứu có trình độ từ THCS trở xuống chiếm $64,2 \%$ thì tî lệ hài lòng chung với dich vu KCB là $91,8 \%(5)$.

Về phân bố địa lý, người ở nông thôn tham gia nghiên cứu của chúng tôi chiếm tỉ lệ $62,5 \%$ và lao động tự do chiếm tỉ lệ $64,29 \%$, các đặc điểm này phù hợp với đối tượng phục vụ của một bênh viên tuyến tỉnh, được xem là tuyến chuyên môn cao nhất của ngành y tế tỉnh nhà để người bệnh chọn lựa đến khám nhất là khi đã có khoảng $89 \%$ người dân trong tỉnh có tham gia BHYT tự nguyên.

2. Sự hài lòng của khách hàng về dịch vụ CĐHÁ

Sự hài lòng của khách hàng về khía cạnh "Tin cậy": Kết quả cho thấy trung bình điểm hài lòng chung là 4,12 $\pm 0,74$ điểm, đạt tỉ lệ 75,3\% số người bệnh tham gia nghiên cứu. Đối với khía canhh "tin cậy" thì yếu tố được người bênh hài lòng nhất là sự công khai quy trình $\mathrm{C} Đ H A$ chiếm tỉ lệ $83,57 \%$; tiếp theo là biết được tình trạng bệnh của bản thân và được hướng dẫn điều trị rõ ràng; cũng như người bệnh cảm thấy tin tưởng vào kết quả $\mathrm{C} Đ H A$. Yếu tố được hài lòng ít nhất trong khía cạnh này là "sự rõ ràng của báo cáo kết quả CĐHA" có tỉ lệ $81,43 \%$. Có thể sự mong muốn nhận được thông tin về bệnh tật của mình rõ ràng, đầy đủ là kỳ vọng mà người bệnh quan tâm khi sử dụng dịch vụ nên sẽ làm cho người bênh khó hài lòng hơn. Nghiên cứu của Hoàng Ngọc Quyên cũng cho thấy các yếu tố tin cậy ảnh hưởng đến sự hài lòng bao gồm sự minh bạch, rõ ràng mà nhà cung cấp dịch vụ đã cam kết với người bệnh ${ }^{(3)}$. Nghiên cứu của Wafaa chì ra rằng yếu tố người bệnh nhận được đầy đủ thông tin cũng ảnh hưởng đến mức độ hài lòng của dịch vụ, tác giả đã cho thấy trong khi sự hài lòng chung của dịch vụ CĐHA tại bệnh viện trường Đại học Fayoum là gần $75 \%$ thì yếu tô người bệnh nhận được đầy đủ thông tin chỉ đạt tỉ lệ hài lòng là $29,3 \%{ }^{(8)}$.

Sự hài lòng của khách hàng vê khía cạnh "Đáp ứng": Khía cạnh đáp ứng bao gồm các tiểu mục để đánh giá việc tổ chức thực hiện dịch vụ CĐHA một cách linh hoạt, cung cấp dịch vụ nhanh chóng không để người bệnh phải chờ đợi lâu; làm cho người bệnh phải chờ đợi mà không có lý do rõ ràng, thỏa đáng sẽ tạo ra những cảm nhận tiêu cực của khách hàng về sự hài lòng với dịch vụ. Kết quả cho thây về các yếu tố đáp ứng, điểm trung bình hài lòng chung của người bệnh là 4,12 $\pm 0,78$ điểm với tỉ lệ người hài lòng là $72,86 \%$, khía cạnh này đạt tî lệ hài lòng người bệnh thấp nhất trong nghiển cứu của chúng tôi, xét theo từng yếu tố thì sự hài lòng của người bệnh về yếu tố được khám theo đúng thứ tự chiếm tỉ lệ cao nhất là $81,43 \%$, còn các yếu tố thông báo chính xác về thời gian khám 
và trả kết quả, cũng như tổ chức thực hiện dịch vụ linh hoạt, đáp ứng kịp thời không để người bệnh chờ đợi lâu đạt tî lệ thấp hơn ở khoảng $77 \%$ đến $78 \%$. Nghiên cứu của Nguyễn Minh Quân (2020) tại BV quận Thủ Đức đo lường mức độ hài lòng của 454 người bệnh nội trú với dịch vụ khám chữa bệnh bằng thang đo Likert dựa theo bảng câu hỏi có cấu trúc, kết quả sự hài lòng của người bệnh đối với dịch vụ CĐHA đạt thấp nhất với số điểm là $2,98 / 5$, trong khi điểm hài lòng chung của người bệnh đối với khu nội trú là 3,27/5, yếu tố khách hàng không hài lòng nhất là mất nhiêu thời gian chờ đợi để được thực hiện dịch vụ̂(2).

Sự hài İòng của khách hàng về khía cạnh "Năng lực phục vụ": Khía cạnh này bao gồm các tiểu mục để đánh giá sự hòa nhã tôn trọng vấn đề riêng tư của người bệnh cũng như kiến thức, khả năng chuyên môn của NVYT trong việc tạo lòng tin, sự tín nhiệm cho người bệnh Kết quả khảo sát về khía cạnh này cho thấy sự hài lòng của người bệnh với dịch vụ bao gồm yếu tố "NVYT luôn tỏ ra lịch sự, tồn trọng những vấn đề riêng tư của người bệnh" chiếm tỉ lệ 84,64\%; các yếu tố như NVYT thực hiện kỹ thuật một cách tỉ mì và toàn diện; giỏi chuyên môn; có kiến thức tốt để sẵn sàng trả lời những câu hỏi của người bệnh đạt tỉ lệ khoảng $80 \%$ đến $81 \%$. Tỉ lệ trung bình hài lòng chung của người bệnh về "nắng lực phục vụ" đạt 76,79\% với điểm trung bình là 4,17 $\pm 0,75$ điểm, có $23 \%$ người bệnh được hỏi không hài lòng về khía cạnh này. Tương tự như nghiên cứu của tác giả Hoàng Ngọc Quyền tại Trung tâm CĐHA Bệnh viện Hữu Nghị Việt Đức, yếu tố "năng lực phục vụ" cũng chỉ đạt thang điểm ở mức trung bình là 3,34 và $12,7 \%$ người bệnh ý kiến cho rằng bác sĩ khám nhanh và không giải thích cặn kẽ cho người bệnh ${ }^{(3)}$. Điều này có thể hiểu do bác sĩ CĐHA và người bệnh chỉ giao tiếp với nhau gián tiếp qua máy móc và trang thiết bị chẩn đoán, trong khi người bệnh cảm thây cần thiết được tiếp xúc trực tiếp với bác sĩ vì chỉ có sự tương tác trực tiểp mới làm cho người bệnh tin tưởng vào chẩn đoán của bác sĩ. Do đó, các bác sĩ CĐHA nên hiểu lĩnh vực mà họ đang tham gia, phải cải thiện cách tiếp cận với người bệnh của mình để đáp ứng nhiều hơn cho sự hài lòng của họ.

Sự hài lòng của khách hàng về khía cạnh "Hữu hình": Khía cạnh "Hữu hình" bao gồm những điều kiện cơ sở vật chất, trang thiết bị, trang phục, giao tiếp của NVYT. Môi trường xung quanh các khoa phòng trong bệnh viện là một bằng chứng hữu hình về sự quan tâm, chăm sóc của những người cung cấp dịch vụ. Kết quả thu được cho thây sự hài lòng của 280 người bệnh ở khía cạnh "Hữu hình" về các yếu tố NVYT ăn mặc sạch sẽ gọn gàng; tiếp xúc người bệnh vui vẻ; TiTB phương tiện chẩn đoán đầy đủ đạt trên 4,2 điểm với tỉ lệ hài lòng đạt $84 \%$ đến $86 \%$, yếu tố nơi ngồi chờ sạch sẽ, ngăn nắp đạt thấp hơn là 4,14 điểm và tî lệ người bệnh hài lòng là $77,86 \%$. Như vậy, yếu tố được người bệnh kỳ vọng nhất trong khía cạnh "Hữu hình" khi đến sử dụng dịch vụ CĐHA là về cơ sở vật chất, cụ thể là "nơi ngồi chờ sạnh sẽ, ngăn nắp". Kết quả của chúng tôi cũng tương tự như trong nghiên cứu của Mulisa và cộng sự đánh giá sự hài lòng trên 321 người bệnh bằng công cụ SERVQUAL, trong khi sự hài lòng với khả năng tiếp cận của dịch vụ là $84,5 \%$, thái độ lịch sự của nhân viên là $80,6 \%$ thì tî lệ người bệnh hài lòng với cơ sở vật chất chỉ đạt $59,4 \%{ }^{(7)}$.

Sự hài lòng của khách hàng về khía cạnh "Đông cảm": điểm trung bình hài lòng chung của người bệnh về yếu tố này là 4,15 điểm với tỉ lệ $73,93 \%$. Trong đó các tiểu mục dịch vụ CĐHA được bố trí phù hợp, đáp ứng kịp thời cho người bệnh; NVYT luôn sắn lòng giúp đõ người bệnh; NVYT có giải thích rõ ràng và yêu cầu hợp tác khi thực hiện kỹ thuật $\mathrm{C} \boxminus \mathrm{HA}$ đạt điểm hài lòng người bệnh là 4,15 với số người đồng ý khoảng $80 \%$. Đạt điểm hài lòng thấp nhất ở khía cạnh này là "sự chia sẻ, động viên của NVYT trước những lo lắng về bệnh tật của người bệnh" với 4,09 điểm và số người hài lòng khoảng $77 \%$. Kết quả nghiên cứu của tác giả Hoàng Ngọc Quyên cũng tương tự( 3$)$, các yếu tố trong thang đo về sự đồng cảm đạt trung bình từ 3,3 đến 3,97 điểm và chỉ có $27 \%$ ý kiến đồng ý là NVYT có quan tâm đến nhu cầu của người bệnh. Có thể hiểu kỳ vọng của người bệnh về khía cạnh "đồng cảm" ở đây là sự lắng nghe, thấu hiểu những nhu cầu của người bệnh, có nhiều lý do để người bệnh cảm thây chưa được chia sẻ. Có thể do đặc thù của chuyên ngành CĐHA mà NVYT nhất là bác sĩ CĐHA làm việc chủ yếu với các TTB và phim ảnh, giao tiếp với người bệnh gián tiếp qua phiếu chỉ định và thực hiện theo y lệnh của bác sĩ lâm sàng, bác sĩ CĐHA thường chẩn đoán bệnh qua các phim chụp chứ không khám trực tiếp người bệnh. Đây chính là yếu tố cần phải được bác sĩ CĐHA chú trọng cải thiện hơn nữa.

Sự hài lòng chung của người bệnh: Tỉ lệ hài lòng chung của người bệnh là $67,14 \%$ và không hài lòng chiếm khoảng $32,86 \%$. Kết quả này thấp hơn kết quả nghiên cứu của tác giả Nguyễn Văn Thắm đánh giá chất lượng dịch vụ chăm sóc 
da tại khoa khám bệnh, Bệnh viện da liễu Thành phố Cần Thơ với tỉ lệ khách hàng đồng ý dịch vụ có chất lượng chung là $81,1 \%$, điểm trung bình chung chất lượng dịch vụ là 4,25(SD = $\pm 0,72)^{(5)}$.

\section{KẾT LUÂNN}

Kết quả nghiên cứu trên 280 người bệnh cho thấy tỉ lệ hài lòng chung đối với dịch vụ $\mathrm{C} Đ H A$ là $67,14 \%$. Tất cả các yếu tố của sự hài lòng đều đạt tỉ lệ dưới $80 \%$.

- Yểu tố "tin cậy" đạt tỉ lệ 75,36\%

- Yếu tố "đáp ứng" đat tỉ lệ $72,86 \%$

- Yễu tố "năng lực phục vư" đat 76,79\%

- Yếu tố "hữu hình" đạt tỉ lệ 74,64\%

- Yếu tố "đồng cảm" đạt tỉ lệ 73,93\%

\section{TÀI LIÊU THAM KHẢO}

1. Bô Y tế (2013), "Bô tiêu chí đánh giá chất lượng bệnh viện", Quyết định số 4858/QĐ-BYT, ngày 03 tháng 12 năm 2013 của Bộ trưởng Bộ Y tế.

2. Nguyễn Minh Quân (2020). "Thực trang và hiệu quả mô hình can thiệp nâng cao chất lượng khám chữa bệnh tại Bệnh viện quận Thủ Đức"', Luận văn Tiến sĩ Y học, Trường Đại Học Y Dược Huế

3. Hoàng Ngọc Quyên. (2020). "Chất lượing dịch vụ khám bệnh tại trung tâm Chẩn đoán hình ảnh, bệnh viện Hữu Nghị Việt Đức". Luận văn thạc sĩ quản trị kinh doanh. Học viện Khoa hộc và Xã hội.

4. Vương Quan Thành (2016). "Sự hài lòng của người bệnh về dịch vụ khám bệnh ngoại trú tại khoa khám bệnh và giải pháp cải thiện tại bệnh viện Quân Dân Y Đồng Tháp". Luận văn Chuyên Khoa II Tổ Chức Quản Lý Y Tế, Trường Đại Học Y Tế Công Cộng.

5. Nguyễn Văn Thắm (2018). Chất lượng dịch vụ chăm sóc da tại khoa khám - Bênh viên Da liễu Thành phố Cần Thơ và một số yểu tố ảnh hưởng năm 2018. Hà Nội: Trường Đại học $Y$ tế công cộng; 2018

6. Nguyê̂n Quốc Viêt (2016). "Đánh giá sư hài lòng của người bệnh và một số giải pháp cải thiện dich vu khám bênh tai khoa khám bệnh, bệnh viển Chỉnh Hình Và Phục Hồi Chức Năng Thành Phố Hî̀ Chí Minh". Luận vằn Chuyên Khoa II Tổ Chức Quản Lý Y Tế, Trường Đại Học Y Tế Công Cộng.

7. Parasuraman A, Valarie A. Zeithaml, Leonard L. Berry. (1985). "A Conceptual Model of Service Quality and Its Implications for Future Research". Journal of Marketing, 49(4): 41-50.

8. Wahed, Wafaa \& Mabrook, Shaimaa \& Abdel Wahed, Wafaa. (2017). "Assessment of patient satisfaction at Radiological Department of Fayoum University Hospitals". International Journal of Medicine in Developing Countries, 1(3): 126-131.

\section{RỐI LOẠN CHỨC NĂNG TÂM TRƯƠNG THẤT TRÁI Ở BẾNH NHÂN XƠ' GAN DO VIRUS VIÊM GAN B}

\section{TÓM TẮT}

Mục tiêu: Nghiên cứu chức năng tâm trương thất trái trên siêu âm tim ở bênh nhân (BN) xơ gan do virus viêm gan $B$ (HBV). Đối tượng và phương pháp: Nghiên cứu mô tả, cắt ngang trên $68 \mathrm{BN}$ xơ gan do HBV Child - Pugh B, C và 30 người nhóm chứng tai Trung tâm Bênh nhiêt đới và Viên Tim mach Bệnh viện Bạch Mai từ tháng 7/2020 đến tháng 8/2021. Các thông số nghiên cứu (NC) trên siêu âm tim: vận tốc $e^{\prime}$ vòng van hai lá ( $e^{\prime}$ vách, $e^{\prime}$ bên), tỷ lệ $\mathrm{E} / \mathrm{e}^{\prime}$ trung bình $\left(\mathrm{E} / \mathrm{e}^{\prime} \mathrm{TB}\right)$, chỉ số thể tích nhĩ trái tối đả (LAVi $\mathrm{ml} / \mathrm{m}^{2}$ ), và vận tốc tối đa dòng hở van ba lá (TRV m/s). Kết luận: Vận tốc e' vách, e' bên giảm, tỷ lệ E/e'TB tăng, TRV tăng, LAVi tăng ở nhóm xơ gan do HBV khi so sánh với nhóm chứng, $\mathrm{p}<0.01 ; 48.5 \% \mathrm{BN}$ xơ gan do HBV có rối loạn CNTTr thất trái. Mức độ

${ }^{1}$ Trường Đai hoc y Hà Nọi

${ }^{2}$ Viện tim mạch Việt Nam, Bệnh viện Bạch Mai

${ }^{3}$ Trung tâm Bênh nhiết đới, Bênh viên Bach Mai

Chịu trách nhiệm chính: Ngô Thị Thanh Loan

Email: bsngoloan@gmail.com

Ngày nhận bài: 12.8.2021

Ngày phản biên khoa hoc: 8.10 .2021

Ngày duyệt bài: 12.10 .2021
Ngô Thi Thanh Loan', Phạm Thị Hồng Thi², Đố Duy Cường ${ }^{3}$, Nguyễn Thị Thu Hoài ${ }^{2}$

Child - Pugh $C(p<0.001)$, sự xuất hiện cổ trướng $(\mathrm{p}<0.001)$ và INR $\geq 1.3(\mathrm{p}=0.001)$ là những yếu tố có ý nghĩa dự báo khả năng bị rối loạn CNTTr ở bệnh nhân xớ gàn do HBV.

Tư khóa: Xơ gan; chức năng tâm trương thất trái.

\section{SUMMARY}

\section{LEFT VENTRICULAR DIASTOLIC}

DYSFUNCTION IN PATIENTS WITH

HEPATITIS B VIRUS-RELATED CIRRHOSIS

Objjectives: Study of left ventricular diastolic function by echocardiography in patients with hepatitis $B$ virus-related cirrhosis. Patients and methods: Cross-sectional descriptive study was carried out on 68 HBV related cirrhotic patients and 30 matched subjects without a previous history of cardiac in Bach Mai Hospital from July 2020 to August 2021. All study participants underwent cardiac assessment with echocardiography, the parameters assessed included annular $\mathrm{e}^{\prime}$ velocity (septal $\mathrm{e}^{\prime}$, ateral $\mathrm{e}^{\prime}$ ), average $\mathrm{E} / \mathrm{e}^{\prime}$ ratio, LA maximum volume index (LAVi $\mathrm{ml} / \mathrm{m}^{2}$ ), and peak TR velocity (TRV m/s). Results: Annular $\mathrm{e}^{\prime}$ velocity was lower, average $\mathrm{E} / \mathrm{e}^{\prime}$ ratio was higher, LAVi and TRV were higher in the HBV related cirrhotic group $(p<0.01) .48 .5 \%$ of patients with HBV related 